\title{
Synaptic Clustering of PSD-95 Is Regulated by c-Abl through Tyrosine Phosphorylation
}

\author{
Karen Perez de Arce, ${ }^{1}$ Lorena Varela-Nallar, ${ }^{1,2}$ Olivia Farias, ${ }^{1}$ Alejandra Cifuentes, ${ }^{3}$ Paulina Bull, ${ }^{3}$ Brian A. Couch, ${ }^{4}$ \\ Anthony J. Koleske, ${ }^{4}$ Nibaldo C. Inestrosa, ${ }^{2}$ and Alejandra R. Alvarez ${ }^{1}$ \\ ${ }^{1}$ Laboratorio de Señalización Celular, Departmento de Biología Celular y Molecular and ${ }^{2}$ Centro de Envejecimiento y Regeneración, Centro de Regulación \\ Celular y Patología Joaquín V. Luco, and 3Departamento Genética Molecular y Microbiología, Facultad de Ciencias Biológicas, Pontificia Universidad \\ Católica de Chile, 8331010 Santiago, Chile, and ${ }^{4}$ Department of Molecular Biophysics and Biochemistry, School of Medicine, Yale University, New Haven, \\ Connecticut 06520
}

The c-Abl tyrosine kinase is present in mouse brain synapses, but its precise synaptic function is unknown. We found that c-Abl levels in the rat hippocampus increase postnatally, with expression peaking at the first postnatal week. In $14 \mathrm{~d}$ in vitro hippocampal neuron cultures, $\mathrm{c}$-Abl localizes primarily to the postsynaptic compartment, in which it colocalizes with the postsynaptic scaffold protein postsynaptic density protein-95 (PSD-95) in apposition to presynaptic markers. c-Abl associates with PSD-95, and chemical or genetic inhibition of c-Abl kinase activity reduces PSD-95 tyrosine phosphorylation, leading to reduced PSD-95 clustering and reduced synapses in treated neurons. c-Abl can phosphorylate PSD-95 on tyrosine 533, and mutation of this residue reduces the ability of PSD-95 to cluster at postsynaptic sites. Our results indicate that c-Abl regulates synapse formation by mediating tyrosine phosphorylation and clustering of PSD-95.

\section{Introduction}

The postsynaptic density protein-95 (PSD-95) is one of the most abundant proteins present at excitatory postsynaptic sites in the CNS (Cho et al., 1992; Kistner et al., 1993). PSD-95 binds other postsynaptic molecules, including NMDA receptors and signaling molecules (Kim and Sheng, 2004). This scaffolding protein is the earliest detectable protein in the PSD and is involved in the maturation of excitatory synapses (Rao et al., 1998; El-Husseini et al., 2000a; Friedman et al., 2000; Prange and Murphy, 2001; Kim and Sheng, 2004). Therefore, regulation of PSD-95 synaptic clustering during development is likely essential for proper synapse formation. Previous studies indicate that posttranslational modifications, such as palmitoylation (Craven et al., 1999; El-Husseini et al., 2000b) and Ser/Thr phosphorylation (Morabito et al., 2004; Sabio et al., 2004; Soto et al., 2004; Gardoni et al., 2006; Kim et al., 2007), control the dynamic recruitment of PSD-95 at the synapse. Recently, it has been suggested that tyrosine phosphorylation could be an additional mechanism for PSD-95 regulation (Du et al., 2009).

\footnotetext{
Received April 28, 2009; revised Jan. 14, 2010; accepted Jan. 20, 2010.

This work was supported by Fondo Nacional de Desarrollo Científico y Tecnológico Grants 1040782 and 1080221 (to A.R.A.), Postdoctoral Fellowship 3070017 (to L.V.-N.), Fondo de Investigación Avanzada en Áreas PrioritariasBiomedicine Grant 13980001, the Millennium Institute for Fundamental and Applied Biology, Mejoramiento de la Calidad y la Equidad de la Educación Superior-Pontificia Universidad Católica de Chile Fellowship Grant 0780 (to K.P.A.), and National Institutes of Health Grant NS39475 (to A.J.K.). We thank Novartis for their gift of STI571, Dr. Zhi-Min Yuan (Department of Genetics and Complex Diseases, Harvard School of Public Health, Boston, MA) for the GFP-c-Abl WT and GFP-c-Abl-KD plasmids, and Dr. Roger Nicoll (Department of Cellular and Molecular Pharmacology, University of California, San Francisco, CA) for the GFP-tagged PSD-95 plasmid.

Correspondence should be addressed to Dr. Alejandra R. Alvarez, Laboratorio Señalización Celular, Departamento de Biología Celular y Molecular, Pontificia Universidad Católica de Chile, Alameda \#340, P.0. Box 114-D, Santiago 8331010, Chile. E-mail: aalvarez@bio.puc.cl.

D0I:10.1523/JNEUROSCI.2024-09.2010

Copyright $\odot 2010$ the authors $\quad 0270-6474 / 10 / 303728-11 \$ 15.00 / 0$
}

Growing evidence has revealed that $A b l$ family tyrosine kinases play important roles in development of the CNS (Moresco and Koleske, 2003). c-Abl belongs to the Abl family and has been implicated in different neuronal processes, including neurulation and neurite outgrowth (Koleske et al., 1998; Lanier and Gertler, 2000; Zukerberg et al., 2000; Woodring et al., 2002; Jones et al., 2004). In addition, c-Abl has been implicated in neurodegenerative diseases, in which c-Abl activation has a central role in signal transduction pathways underlying pathogenesis of Alzheimer and Niemann Pick diseases (Alvarez et al., 2004a, 2008; Cancino et al., 2008). In adult mice, c-Abl is localized in the synaptic compartments (Moresco et al., 2003). Electrophysiological studies in $c-A b l^{-/-}$mice have shown that $\mathrm{c}-\mathrm{Abl}$ is required for the regulation of neurotransmitter release at Schaffer collateral-CA1 synapses (Moresco et al., 2003). Evidence for postsynaptic structure requirement of $\mathrm{c}-\mathrm{Abl}$ has been reported during synapse formation at the neuromuscular junction (Finn et al., 2003). Additionally, c-Abl has been involved in NMDA receptor regulation downstream to $\mathrm{PDGF} \beta$ receptor in hippocampal slices (Beazely et al., 2008). However, the specific role of c-Abl at postsynaptic structures in CNS is unknown. It has been reported that c-Abl interacts with Src kinases and phosphorylation by Src lead to enhanced c-Abl activity (Tanis et al., 2003; Chen et al., 2008). Interestingly, evidence shows that Src/Fyn modulates the PSD-95 tyrosine phosphorylation, and it has been suggested that this phosphorylation contributes to the facilitating effect of PSD-95 on NMDAmediated currents (Du et al., 2009). Therefore, it is possible that c-Abl could contribute to the PSD-95 regulation and consequently modulate postsynaptic development and function.

We evaluated whether c-Abl kinase is a novel posttranslational modulator of PSD-95 clustering. We established that c-Abl activity is important for synaptic contact establishment and for PSD-95 clus- 
tering in vitro and in vivo. Moreover, c-Abl phosphorylates PSD-95 at tyrosine 533. Our results demonstrate that c-Abl acts as an PSD-95 modulator and show for the first time that tyrosine phosphorylation plays a role in the PSD-95 clustering.

\section{Materials and Methods}

Primary culture of rat hippocampal neurons. Rat hippocampal cultures were prepared as described previously with some modifications (Alvarez et al., 2004b; Kaech and Banker, 2006). Hippocampi from Sprague Dawley rats at embryonic day 18 were removed, dissected free of meninges in $\mathrm{Ca}^{2+} / \mathrm{Mg}^{2+}$-free HBSS, and rinsed twice with HBSS by allowing the tissue to settle to the bottom of the tube. After the second wash, the tissue was resuspended in HBSS containing 0.25\% trypsin and incubated for 15 min at $37^{\circ} \mathrm{C}$. After three rinses with HBSS, the tissue was mechanically dissociated in plating medium (DMEM; Invitrogen), supplemented with $10 \%$ horse serum (Invitrogen), $100 \mathrm{U} / \mathrm{ml}$ penicillin, and $100 \mu \mathrm{g} / \mathrm{ml}$ streptomycin by gentle passage through Pasteur pipettes. Dissociated hippocampal cells were seeded onto poly-L-lysine-coated six-well culture plates at a density of $7 \times 10^{5}$ cells per well in plating medium. Cultures were maintained at $37^{\circ} \mathrm{C}$ in $5 \% \mathrm{CO}_{2}$ for $2 \mathrm{~h}$ before the plating medium was replaced with Neurobasal growth medium (Invitrogen) supplemented with B27 (Invitrogen), 2 mM L-glutamine, $100 \mathrm{U} / \mathrm{ml}$ penicillin, and $100 \mu \mathrm{g} / \mathrm{ml}$ streptomycin. At day 2, cultured neurons were treated with AraC $2 \mu \mathrm{M}$ for $24 \mathrm{~h}$; this method resulted in cultures highly enriched for neurons ( $\sim 5 \%$ glia). For hippocampal cultures from $c-A b l^{-/-}$mice, we used the ablm2 mutant (Tybulewicz et al., 1991) because it is a true Abl protein null. Each $\mathrm{Abl}^{-/-}$mouse was matched with a wild-type (WT) embryo control.

Immunofluorescence. Hippocampal neurons were seeded onto poly-Llysine-coated coverslips in 24 -well culture plates at a density of $2.5 \times 10^{4}$ cells per well. Cells were rinsed twice in ice-cold PBS, fixed with a freshly prepared 4\% paraformaldehyde/4\% sucrose in PBS for $20 \mathrm{~min}$, and permeabilized for 5 min with $0.2 \%$ Triton X-100 in PBS. After several rinses in ice-cold PBS, cells were incubated in $0.2 \%$ gelatin in PBS (blocking solution) for $30 \mathrm{~min}$ at room temperature, followed by an overnight incubation at $4^{\circ} \mathrm{C}$ with primary antibodies. The cells were extensively washed with PBS and then incubated with Alexa-conjugated secondary antibodies (Invitrogen) $30 \mathrm{~min}$ at $37^{\circ} \mathrm{C}$. The cells were mounted in mounting medium and analyzed by confocal microscopy. Primary antibodies (Santa Cruz Biotechnology) used were as follows: mouse anti-c-Abl, rabbit anti-glutamate receptor 1 (GluR1), rabbit anti-microtubule-associated protein 2 (MAP2), rabbit anti-synapsin I (Syn I), and goat anti-synaptic vesicle protein 2 (SV2). The monoclonal antibodies anti-PSD-95, anti$\mathrm{NR} 2 \mathrm{~B}$, anti-pan-SHANK (SH3 and multiple ankyrin repeat domain protein), and anti-vesicular glutamate transporter 1 (vGLUT1) was developed by and obtained from the University of California, Davis/ National Institutes of Health (NIH) NeuroMab Facility, supported by NIH Grant U24NS050606 and maintained by the Department of Neurobiology, Physiology, and Behavior, College of Biological Sciences, University of California, Davis.

Confocal images of neurons were obtained using a Carl Zeiss 633 (numerical aperture 1.4) objective with sequential acquisition settings at the maximal resolution of the confocal $(1024 \times 1024$ pixels $)$. The confocal microscope settings were kept the same for all scans when fluorescence intensity was compared. All measurements were performed using NIH ImageJ software.

Subcellular fractionation. For postsynaptic density (PSD) isolation, the method of Carlin et al. (1980) was slightly modified. Briefly, the telencephalon of 10 male Sprague Dawley rats were dissected, cut, and homogenized on ice in $8 \mathrm{ml}$ of homogenization buffer $(0.32 \mathrm{M}$ sucrose, 0.5 mM EGTA, and $5 \mathrm{~mm}$ Tris, $\mathrm{pH} 7.4$ ), using 12 strokes with a $40 \mathrm{ml}$ Tissue Grind Potter with Teflon Pestle (Thomas Scientific). Subsequent fractionation followed the procedures described previously (Wyneken et al., 2001). Then, the telencephalon homogenate was centrifuged at $1000 \times g$ for $10 \mathrm{~min}$ at $4^{\circ} \mathrm{C}$, and the supernatant (S1) was saved. The pellet (P1) was washed, manually homogenized, and centrifuged at $1000 \times g$ for $10 \mathrm{~min}$ at $4^{\circ} \mathrm{C}$. The pellet (P2) was discarded, and the supernatant (S2) was mixed with S1. S1 plus S2 were centrifuged at $12,000 \times g$ for $20 \mathrm{~min}$ at $4^{\circ} \mathrm{C}$. The pellet (P3) was saved and rinsed with solution A (0.32 sucrose, $5 \mathrm{~mm}$ Tris- $\mathrm{HCl}, \mathrm{pH}$ 8.1, $0.5 \mathrm{~mm}$ EGTA, and $1 \mathrm{~mm}$ dithiotreitol). Then, the P3 was manually homogenized with a $17 \mathrm{ml}$ Tissue Grind Potter with Teflon Pestle (Thomas Scientific), layered on a discontinuous sucrose step gradient $(0.32 \mathrm{M}, 1 \mathrm{M}$, and $1.2 \mathrm{~m}$ sucrose in $5 \mathrm{~mm}$ Tris- $\mathrm{HCl}, \mathrm{pH} 8.1)$, and centrifuged at $150,000 \times \mathrm{g}$ using the for $2 \mathrm{~h}$ at $4^{\circ} \mathrm{C}$. The synaptosome 1 (S1) fraction was isolated from 1 to $1.2 \mathrm{M}$ sucrose gradient and diluted 10 times with the lysis buffer ( $5 \mathrm{~mm}$ Tris- $\mathrm{HCl}, \mathrm{pH} 8.1$, and 0.5 mm EGTA). Lysis was performed by incubating and gently mixing the lysis buffer with $\mathrm{S} 1$ in ice for $30 \mathrm{~min}$. Then synaptosome 1 was centrifuged at 33,000 $\times \mathrm{g}$ for $30 \mathrm{~min}$. The pellet (P4) was saved, resuspended in $3 \mathrm{ml}$ of solution $\mathrm{A}$, and manually homogenized. Then $\mathrm{P} 4$ was layered on a discontinuous sucrose step gradient $(0.32 \mathrm{M}, 1 \mathrm{M}$, and $1.2 \mathrm{~m}$ sucrose in $5 \mathrm{~mm}$ Tris- $\mathrm{HCl}$, $\mathrm{pH} 8.1$ ) and centrifuged at $250,000 \times g$ for $1 \mathrm{~h}$ at $4^{\circ} \mathrm{C}$. The fraction of synaptosome 2 was obtained from 1 and $1.2 \mathrm{M}$ fractions. S2 was saved and diluted with 8 vol of $0.32 \mathrm{M}$ sucrose, $0.025 \mathrm{~mm} \mathrm{CaCl}_{2}, 1 \%$ Triton X-100, 2 mM DTT, and $10 \mathrm{~mm}$ Tris- $\mathrm{HCl}$, pH 8.1. S2 fraction was gently mixed in this buffer and centrifuged at $33,000 \times \mathrm{g}$ for $30 \mathrm{~min}$ at $4^{\circ} \mathrm{C}$. The pellet (P5) is the PSD fraction. It was saved and washed with 50 mM HEPES, $\mathrm{pH}$ 7.4. The PSDs were centrifuged at $250,000 \times g$ for $10 \mathrm{~min}$ at $4^{\circ} \mathrm{C}$, and the pellet was resuspended in $50 \mathrm{~mm}$ HEPES, pH 7.4. The PSD fraction was frozen in liquid nitrogen and stored at $-80^{\circ} \mathrm{C}$. Protein concentration in the PSD fraction and total telencephalon homogenate samples was determined by the BCA method. The PSD and total homogenate samples were diluted $1: 1$ with loading buffer and heated at $100^{\circ} \mathrm{C}$ for $5 \mathrm{~min}$. Then, 20 and $40 \mu \mathrm{g}$ of protein, respectively, were loaded on a $10 \%$ SDS-PAGE, separated by electrophoresis, and electrotransferred to polyvinylidene difluoride (PVDF) membrane.

Immunoblot analysis. Treated cells were washed with ice-cold PBS and immediately lysed with radioimmunoprecipitation assay (RIPA) buffer containing (50 mm Tris, $150 \mathrm{~mm} \mathrm{NaCl}, 1 \mathrm{~mm}$ EGTA, 1 mm EDTA, 0.5\% deoxycholate, $1 \% \mathrm{NP}-40$, and $0.1 \%$ SDS) supplemented with protease inhibitors ( $1 \mathrm{~mm}$ PMSF, $1 \mu \mathrm{g} / \mathrm{ml}$ aprotinin, $10 \mu \mathrm{g} / \mathrm{ml}$ leupeptin, $1 \mathrm{~mm}$ $\mathrm{Na} 3 \mathrm{VO}$, and $50 \mathrm{~mm} \mathrm{NaF}$ ). The homogenates were maintained in ice for $30 \mathrm{~min}$ and then were centrifuged at $1000 \times g$ for $5 \mathrm{~min}$. The supernatant was recovered, and protein concentration was determined by BCA protein assay kit (Pierce). Proteins were resolved in SDS-PAGE (10\% polyacrylamide), transferred to PVDF membrane, and reacted with primary antibodies. The reactions were followed by incubation with secondary antibodies peroxidase labeled (Pierce) and developed using the ECL technique (PerkinElmer Life and Analytical Sciences). Primary antibodies were the same used for immunofluorescence in addition to rabbit anti- $\beta$-tubulin, rabbit anti-N-cadherin, rabbit anti-Syn I, mouse antiGluR1, rabbit anti-NMDA receptor subunit 1 (NR1) (Santa Cruz Biotechnology), and mouse anti-vGLUT1 (University of California, Davis/ NIH NeuroMab Facility).

Coimmunoprecipitation assay. Protein extract was obtained from hippocampal cultures lysed in RIPA buffer containing a mixture of protease and phosphatase inhibitors. Adult rat brains were lysed in RIPA buffer, and immunoprecipitations were performed using anti-PSD-95 and antic-Abl antibody. HEK293 cells were lysed in RIPA buffer, and immunoprecipitations were performed from transfected HEK293 cells with PSD-95 and c-Abl plasmids. Complexes were isolated using protein A or protein G Sepharose. Tissue and cell lysates were separated by SDSPAGE, transferred to PVDF membranes (Fisher Thermo Scientific), and immunoblotted with phosphotyrosine (pTyr) antibody (Millipore Bioscience Research Reagents), anti-PSD-95, and anti-c-Abl antibody.

Neuronal transfection. Neurons were transfected using LipofectAMINE 2000 (Invitrogen) $2 \mathrm{~d}$ after seeding on 24 -well (coverslips) or six-well culture plates at a density of $4 \times 10^{4}$ or $1 \times 10^{6}$ cells per well, respectively. Briefly, DNA and Lipofectamine 2000 were mixed in OptiMEM (Invitrogen) according to the instructions of the manufacturer. After $20 \mathrm{~min}$, the DNA-Lipofectamine 2000 Reagent complex was added to the cells. Neurons were incubated at $37^{\circ} \mathrm{C}$, and then the media were replaced with Neurobasal growth medium (Invitrogen) supplemented with B27 (Invitrogen), $2 \mathrm{~mm}$ L-glutamine, $100 \mathrm{U} / \mathrm{ml}$ penicillin, and $100 \mu \mathrm{g} / \mathrm{ml}$ streptomycin.

HEK293 transfection. Cells seeded on six-well culture plates at a density of $70 \%$ were transfected using LipofectAMINE 2000 (Invitrogen), ac- 
cording to the instructions of the manufacturer. HEK293 were incubated with DNA-LipofectAMINE 2000 at $37^{\circ} \mathrm{C}$, and the media were replaced with DMEM (Invitrogen) supplemented with FBS (Hyclone Laboratories), $100 \mathrm{U} / \mathrm{ml}$ penicillin, and $100 \mu \mathrm{g} / \mathrm{ml}$ streptomycin. Cells were harvested $36 \mathrm{~h}$ after transfection and lysed.

In vitro phosphorylation assay. Kinase assay mixtures contained $25 \mathrm{~mm}$ HEPES, pH 7.25, $100 \mathrm{~mm} \mathrm{NaCl}, 5 \mathrm{~mm} \mathrm{MgCl}_{2}, 5 \%$ glycerol, $100 \mathrm{ng}$ of bovine serum albumin/ $\mu \mathrm{l}, 1 \mathrm{~mm}$ sodium orthovanadate, and $10 \mathrm{~nm} \mathrm{c}-\mathrm{Abl}$ kinase. Abl was purified to $>90 \%$ purity as described previously (Tanis et al., 2003). After a $5 \mathrm{~min}$ preincubation at $30^{\circ} \mathrm{C}, 25 \mu \mathrm{l}$ reactions were initiated by the addition of $500 \mathrm{~nm}$ glutathione $S$-transferase (GST)PSD-95 or GST-CrkII, $5 \mu \mathrm{M}$ ATP, and $0.5 \mu \mathrm{Ci}$ of $\left[\gamma^{-}{ }^{32} \mathrm{P}\right] \mathrm{ATP}$. As negative controls of phosphorylation, we used c-Abl kinase denatured by heat and c-Abl kinase incubated with 500 nM STI571 during the reactions. c-Abl incubated with $0.5 \mu \mathrm{Ci}$ of $\left[\gamma^{-}{ }^{32} \mathrm{P}\right] \mathrm{ATP}$ without a substrate was used for normalization. All reaction mixtures were incubated at $30^{\circ} \mathrm{C}$ for different periods of time, and the reaction mixtures were stopped on phosphocellulose P81 paper (Whatman) and washed three times with $0.75 \% \mathrm{v} / \mathrm{v}$ phosphoric acid. Alternatively, the reactions were terminated by the addition of ice-cold SDS sample buffer and were resolved by SDS-PAGE. The gels were dried and were exposed for autoradiography and quantified using a Molecular Dynamics PhosphorImaging system and ImageQuant software.

Site-directed mutagenesis. PSD-95 mutants were generated by PCR using the proofreading Pfu polymerase (Promega), followed by DpnI digestion of the methylated parental plasmid. Oligonucleotides used were as follows: Y255Asense, 5'GAGTGACAGCGCTGCTCCCCCAG; Y255A antisense, 5'CTGGGGGAGCAGCGCTGTCACTC; Y533A sense, 5'GGAAGTGCACGCTGCTCGTCCCA; Y533A antisense, 5'TGGGACGAGCAGCGTGCACTTCC. Each clone was verified by automated sequencing.

Statistical analysis. Mean and SE values and the number of experiments are indicated in each figure. Statistical analysis was performed by one-way ANOVA, followed by Student's $t$ test using SigmaPlot (version 9.0).

\section{Results}

\section{c-Abl is present in synaptic sites in cultured} hippocampal neurons

An increase in the clustering of synaptic proteins such as PSD-95 and SHANK has been observed in hippocampal neurons at 12-14 $\mathrm{d}$ in vitro (DIV) (Gerrow et al., 2006). We analyzed c-Abl distribution in 14 DIV hippocampal neurons to investigate its potential synaptic role. We found that c-Abl is broadly distributed in neurons and shows a punctate staining in neuronal processes (Fig. 1A). To test whether $\mathrm{c}-\mathrm{Abl}$ is present at synaptic sites in cultured neurons, we examined the colocalization with the presynaptic marker Syn I. As observed in Figure 1 B, at 14 DIV, c-Abl clusters are apposed closely to Syn I puncta, suggesting that this kinase is mainly distributed postsynaptically (Fig. $1 B$ ) as reported previously in hippocampal Schaffer collateral-CA1 synapse (Moresco et al., 2003). To further evaluate this, we transfected the construct green fluorescent protein (GFP)-c-Abl-WT, and the colocalization with Syn I or the postsynaptic scaffold protein PSD-95 was analyzed. Along the dendritic shaft, we observed that GFP-c-Abl-WT clusters colocalize with PSD-95 puncta in close apposition to Syn I (Fig. 1C). Application of the intensity correlation analysis plug-in (NIH ImageJ software) on data from confocal images for each synaptic marker on hippocampal neurons transfected with GFP-c-Abl-WT allowed a quantitative description of the presynaptic and postsynaptic colocalization patterns. The Mander's overlap coefficient $(R)$ shows that c-Abl distribution presents a higher overlap degree with PSD-95 rather than Syn I $\left(R_{\text {PSD-95 }}=0.6343 \pm 0.01\right.$ vs $\left.R_{\text {Syn I }}=0.3517 \pm 0.02\right)$. Additionally, this was supported by Mander's colocalization coefficients, which indicates that the c-Abl immunostaining presents a higher colocalization with PSD-95 than with Syn I (M1 $1_{\text {-Abl-WT/PSD-95 }}=$
A

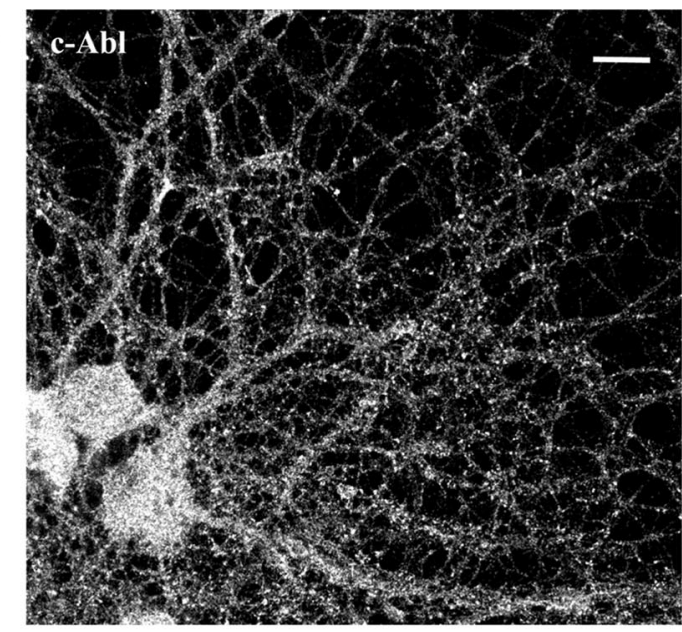

B
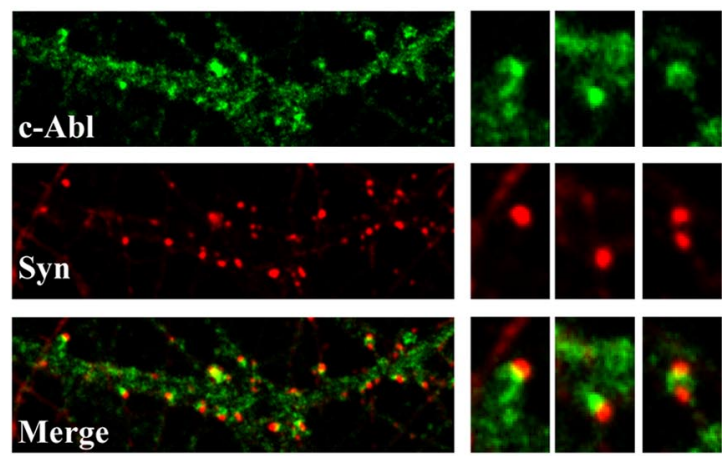

C
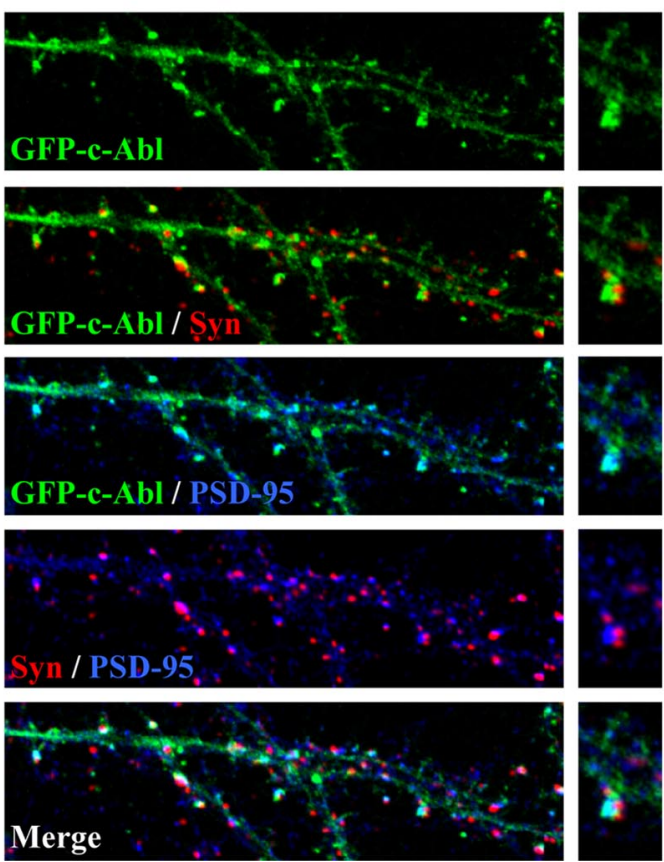

Figure 1. c-Abl is present in synaptic sites in cultured hippocampal neurons. $\boldsymbol{A}$, Immunodetection of c-Abl in hippocampal neurons maintained for $14 \mathrm{~d}$ in culture. Scale bar, $10 \mu \mathrm{m}$. $\boldsymbol{B}$, Representative merged images with the presynaptic marker Syn I indicate that c-Abl clusters are located postsynaptically in close apposition to Syn I puncta. $\boldsymbol{C}$, Neurons were transfected with GFP-c-Abl-WT $2 \mathrm{~d}$ after seeding. After $14 \mathrm{~d}$ in vitro, c-Abl-GFP (green) colocalizes with PSD-95 (blue) close to Syn I puncta (red).

$\left.0.9187 \pm 0.01 ; \mathrm{M}_{\mathrm{c}-\mathrm{Abl}-\mathrm{WT} / \mathrm{Syn} \mathrm{I}}=0.3147 \pm 0.01\right)$. These results strongly suggest that c-Abl is mainly localized on postsynaptic structures. However, we cannot rule out the possible presence of this kinase on the presynaptic region. 

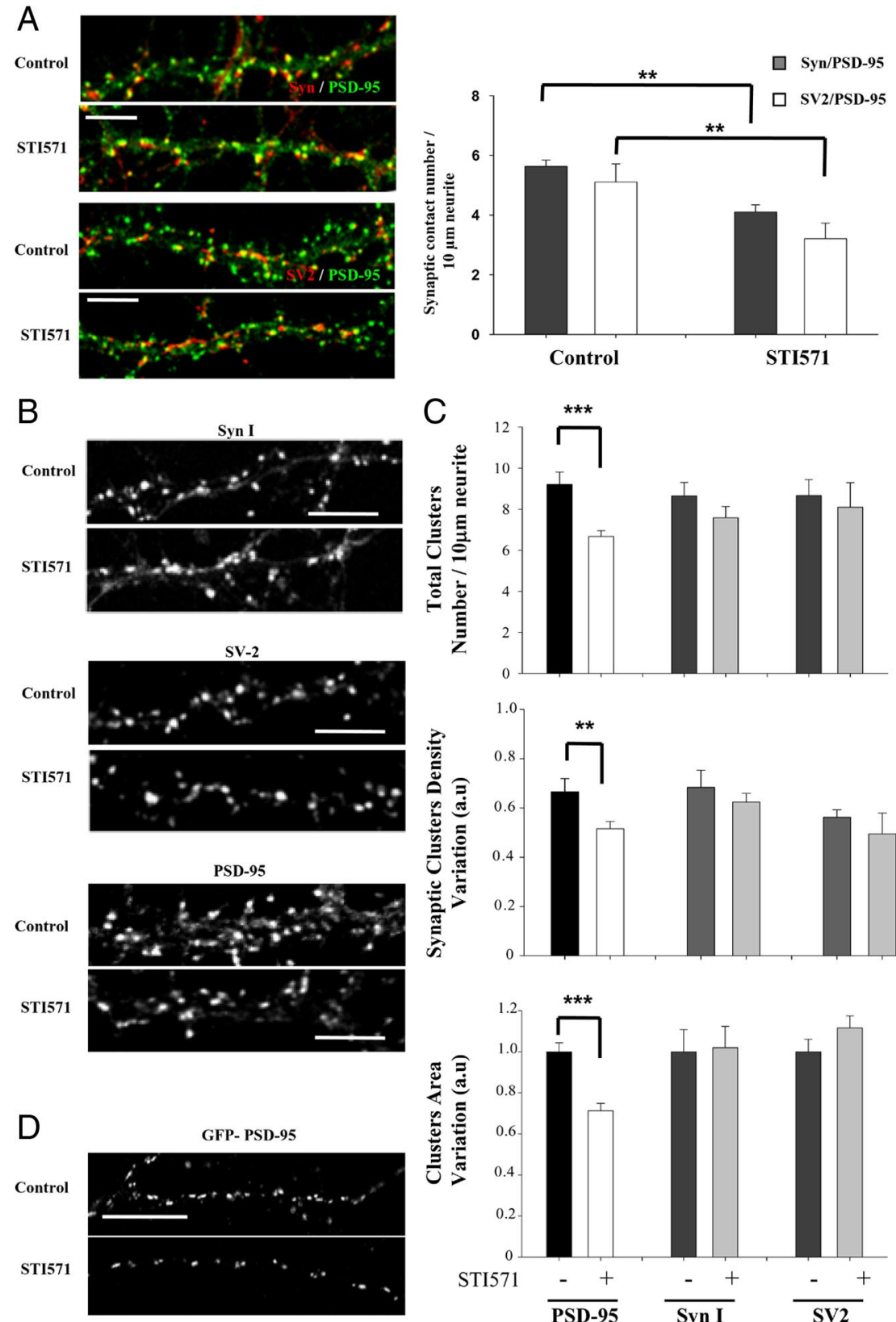
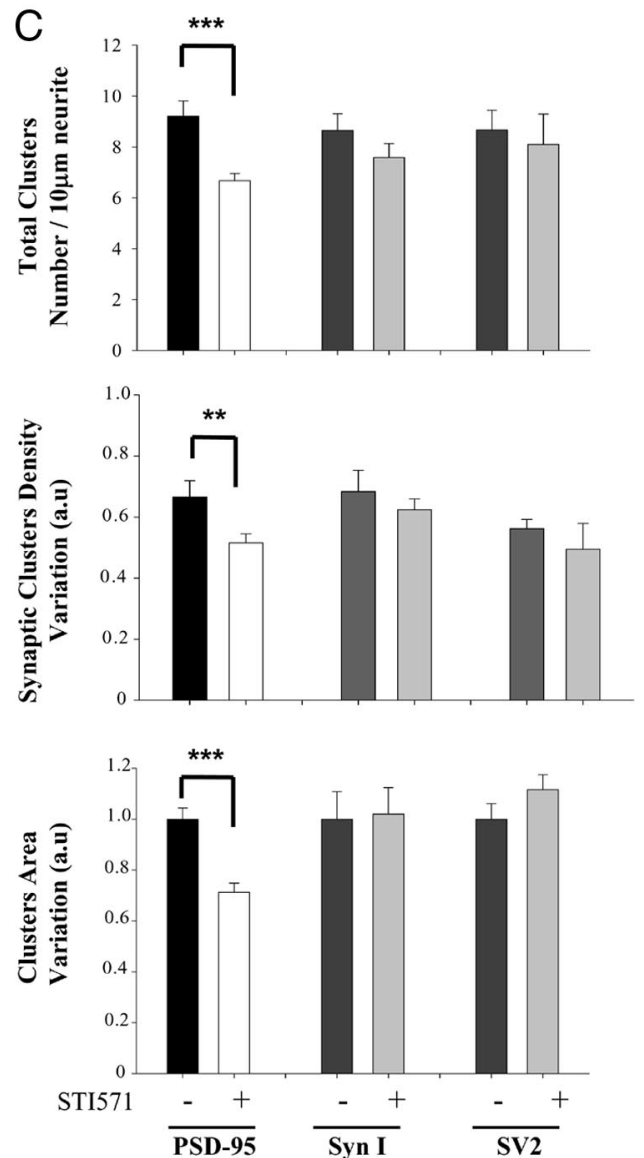

Figure 2. c-Abl modulates the synaptic contact number and PSD-95 clustering. $\boldsymbol{A}$, Neurons at 14 DIV were treated with $1 \mu \mathrm{M}$ STI571 for $24 \mathrm{~h}$, and synaptic contacts were evaluated by immunodetection against PSD-95 (green)/Syn I (red) or PSD-95 (green)/ SV2 (red). B, Representative image of immunofluorescence for presynaptic protein using anti-Syn I, anti-SV2, and the postsynaptic protein PSD-95 in control neurons and those treated with STI571. C, Quantification of the total cluster number per neurite length, synaptic cluster density variation, and area for PSD-95, Syn I, and SV2 in cultured neurons with or without treatment with $1 \mu \mathrm{M}$ STI571 for $24 \mathrm{~h}$. Error bars depict SEM of five independent experiments ( $\left.{ }^{* *} p<0.01{ }^{* * *} p<0.001\right)$. D, Neurons were transfected with PSD-95-GFP before seeding. After $14 \mathrm{~d}$ in vitro, the number of PSD-95 puncta per neurite length was analyzed in the presence or absence of STI571 treatment. Scale bar, $5 \mu \mathrm{m}$.

\section{c-Abl modulates the synaptic contact number and PSD-95 clustering}

The possible role of c-Abl in synaptic structure was evaluated in 14 DIV neurons by treatment with STI571, an inhibitor of the c-Abl kinase activity (Corbin et al., 2002). We evaluated the number of synaptic contacts, identified by PSD-95/Syn I or PSD-95/ SV2 coclusters along the neuronal projection (Fig. $2 \mathrm{~A}$ ). Treatment with $1 \mu \mathrm{M}$ STI571 for $24 \mathrm{~h}$ decreased the number of synaptic contacts per neurite length (control ${ }_{\text {Syn I-PSD-95 }}, 5.6 \pm 0.2 / 10 \mu \mathrm{m}$ neurite vs $\mathrm{STI571}_{\text {Syn I-PSD-95 }}, 4.1 \pm 0.2 / 10 \mu \mathrm{m}$ neurite; control ${ }_{\mathrm{SV} 2-\mathrm{PSD}-95}, 5.1 \pm$

$0.6 / 10 \mu \mathrm{m}$ neurite vs $\mathrm{STI} 571_{\mathrm{SV} 2-\mathrm{PSD}-95}$, $3.2 \pm 0.5 / 10 \mu \mathrm{m}$ neurite; $p<0.01$ ).

The decrease in synaptic contact number could be a consequence of a presynaptic or postsynaptic effect of STI571 or both. To address this, we evaluated the total number of clusters per neurite length, the density of synaptic clusters, and the mean cluster area of presynaptic and postsynaptic markers separately. As shown in Figure 2, $B$ and $C$, STI571 treatment did not significantly decreased the total clusters density (control, $8.6 \pm 0.7 / 10 \mu \mathrm{m}$ neurite; STI571, $7.6 \pm$ $0.5 / 10 \mu \mathrm{m}$ neurite), synaptic cluster density (control, $0.68 \pm 0.07$; STI571, $0.62 \pm 0.03$ ), or cluster area of Syn I (control, $1 \pm 0.11$; STI571, $1.02 \pm 0.10)$. Neither were affected by STI571 total cluster number (control, $8.7 \pm 0.8 / 10 \mu \mathrm{m}$ neurite; STI571, $8.1 \pm$ $1.2 / 10 \mu \mathrm{m}$ neurite), synaptic cluster density (control, $0.56 \pm 0.03$; STI571, $0.49 \pm$ 0.08 ), or the clusters area of SV2 (control, $1 \pm 0.06$; STI571, $1.12 \pm 0.06$ ). Moreover, we analyzed the presynaptic vGLUT1 that is subject to differential regulation during development on glutamatergic synapse (Boulland et al., 2004). STI571 treatment did not alter the number of vGLUT1 clusters per neurite length (control, $11.21 \pm 0.43 / 10$ $\mu \mathrm{m}$ neurite; STI571, $11.23 \pm 0.85 / 10 \mu \mathrm{m}$ neurite) or the cluster area (control, $1 \pm$ 0.09; STI571, $1.06 \pm 0.06$ ) (supplemental Fig. 1, available at www.jneurosci.org as supplemental material). In the postsynaptic region, the effect of STI571 on PSD-95 clustering was evaluated (Fig. 2C). STI571 induced an $\sim 30 \%$ reduction in PSD-95 total cluster number per neurite length (control, 9.2 $\pm 0.6 / 10 \mu \mathrm{m}$ neurite; STI571, $6.6 \pm 0.3 / 10 \mu \mathrm{m}$ neurite; $p<$ 0.001 ) and $\sim 22 \%$ reduction in synaptic PSD-95 cluster density (control, $0.66 \pm$ 0.05 ; STI571, $0.51 \pm 0.03 ; p<0.01)$. In an attempt to determine whether the amount of PSD-95 in the remaining clusters is diminished in the presence of STI571, the area of PSD-95 clusters was evaluated. As shown in Figure $2 C$, the cluster area decreased $\sim 30 \%$ in STI571treated neurons (STI571, $0.71 \pm 0.04$ relative to control). In addition, hippocampal neurons were transfected with the construct coding for PSD-95-GFP, which allowed us to analyze PSD-95 clusters on isolated neurons (Fig. 2D). In 14 DIV transfected neurons, treatment with $1 \mu \mathrm{M}$ STI571 for $24 \mathrm{~h}$ significantly decreased the number of PSD-95-GFP clusters per neurite length $(37.10 \pm 2.3 \%$ decrease; $p<0.001)$. These results suggest that $\mathrm{c}-\mathrm{Abl}$ inhibition affects the postsynaptic region.

To determine whether other scaffold proteins are also affected by STI571 treatment, we analyzed total SHANK cluster density and area. SHANK is one of the most abundant proteins in the postsynaptic density and is important for the structural and func- 
tional organization of the dendritic spine (Sala et al., 2001). We determined that STI571 treatment did not affect SHANK clusters (number of clusters: control, $4.14 \pm 0.31 / 10 \mu \mathrm{m}$ neurite; STI571, $3.77 \pm 0.85 / 10 \mu \mathrm{m}$ neurite; cluster area: control, $1 \pm 0.09$; STI571, $1.10 \pm 0.07$ ) (supplemental Fig. $2 \mathrm{~A}$, available at www. jneurosci.org as supplemental material). In addition, we evaluated whether c-Abl activity modulates dendritic spines, which were visualized with fluorescent phalloidin (supplemental Fig. $2 B$, available at www.jneurosci.org as supplemental material). No significant differences were observed in dendritic spine number per neurite length between control versus STI571-treated neurons (control, $8.19 \pm 0.43 / 10 \mu \mathrm{m}$; STI571, $8.56 \pm 0.52 / 10$ $\mu \mathrm{m})$. These results suggest that c-Abl activity specifically modulates PSD-95 clustering and not the general structure of the postsynaptic compartment.

It has been widely described that PSD-95 regulates the insertion and retention of AMPA receptor at the synapse (El-Husseini et al., 2000a; Schnell et al., 2002; Ehrlich and Malinow, 2004). Therefore, we evaluated the effect of STI571 on the AMPA receptor subunit 1 (GluR1) clustering and determined an almost 23\% reduction in GluR1 cluster density in neurons treated with $1 \mu \mathrm{M}$ STI571 for $24 \mathrm{~h}$ (control, $5.18 \pm 0.37 / 10 \mu \mathrm{m}$ neurite; STI571, $4.02 \pm 0.35 / 10 \mu \mathrm{m}$ neurite; $p<0.05$ ) (supplemental Fig. $2 C$, available at www.jneurosci.org as supplemental material). This result suggests that c-Abl could ultimately influence AMPA receptor clustering during synapse maturation.

An additional approach to establish the role of c-Abl kinase activity on PSD-95 clustering was to transfect neurons with the dominant-negative mutant of c-Abl [kinase-inactive form (GFP$\mathrm{c}-\mathrm{Abl}-\mathrm{KD})]$. First, we analyzed the distribution of this mutant version of c-Abl in neurons. As observed with GFP-c-Abl-WT, GFPc-Abl-KD shows a diffuse staining in the dendritic shaft and a clustered postsynaptic distribution, as it colocalizes with PSD-95 in close apposition to Syn staining (Fig. 3A). This observation was supported by the Mander's overlap coefficient $\left(R_{\mathrm{PSD}-95}=\right.$ $0.6898 \pm 0.02$ vs $\left.R_{\text {Syn I }}=0.3822 \pm 0.03 ; p<0.001\right)$ and Mander's colocalization coefficients for PSD-95 $\left(\mathrm{M}_{\mathrm{GFP}-\mathrm{c}-\mathrm{Abl}-\mathrm{KD} / \mathrm{PSD}-95}=\right.$ $0.9472 \pm 0.02)$ and Syn I (M1 $\left.1_{\mathrm{GFP}-\mathrm{c}-\mathrm{Abl}-\mathrm{KD} / \mathrm{Syn} \mathrm{I}}=0.4750 \pm 0.05\right)$, which show a higher GFP-c-Abl-KD colocalization with PSD-95 rather than Syn I. Thus, the postsynaptic distribution of c-Abl is independent of kinase activity. To determine the role of c-Abl on PSD-95 synaptic clustering, we analyzed the number of PSD-95 puncta number per neurite length in transfected neurons (Fig. 3B). GFP-c-Abl-KD transfection decreased PSD-95 cluster number compared with GFP as control (GFP, $1 \pm 0.03$; GFP-c$\mathrm{Abl}-\mathrm{KD}, 0.51 \pm 0.02 ; p<0.001)$. In addition, there is a significant decrease in synaptic contact number positive for Syn I and PSD-95 (Fig. 3B) in neurons transfected with GFP-c-Abl-KD compared with neurons transfected with GFP (GFP, $1 \pm 0.03$; GFP-c-Abl-KD, $0.54 \pm 0.07 ; p<0.01)$. This result supports a role for c-Abl activity in PSD-95 clustering in hippocampal neurons. To evaluate the synaptic distribution of PSD-95 in the absence of c-Abl, we analyzed PSD-95 clustering in hippocampal neurons obtained from $c-A b l^{-/-}$mice (Koleske et al., 1998). At 14 DIV, hippocampal neurons from knock-out mice (Fig. 3C) show significantly less clusters of PSD-95 per neurite length (wild type, $1 \pm 0.1 ; c-A b l^{-/-}, 0.52 \pm 0.06 ; p<0.01$ ) and a reduction in cluster area (wild type, $1 \pm 0.06 ; c-A b l^{-/-}, 0.67 \pm$ 0.07 ; $p<0.01$ ) compared with neurons from wild-type animals. MAP2 staining was used as control of normal dendritic arborization. Altogether, these results demonstrate that c-Abl activity is required for PSD-95 clustering.

\section{c-Abl interacts with PSD-95 and modulates PSD-95 tyrosine phosphorylation}

Considering that c-Abl modulates PSD-95 clustering, it is possible that there is an interaction between both proteins. To assess this interaction in vitro, we performed a coimmunoprecipitation assay from cultured hippocampal neurons at 14 DIV. The immunoprecipitation with anti-c-Abl antibody followed by PSD-95 immunoblot showed that this postsynaptic scaffold protein forms part of a complex with c-Abl and NR1 (Fig. 4A). To evaluate whether c-Abl/PSD-95 interact in vivo, we first studied the expression of c-Abl in the developing hippocampus. We observed that this kinase is present at low levels at embryonic stage, then increases between postnatal day 2 (P2) and P5, and starts to decrease at P10 and maintains its low level until adult stages (Fig. $4 B)$. Synaptic proteins vGLUT1 and synaptophysin increase from low levels at P2 to high levels in adult. N-cadherin was used as a loading control because it is known to be present at all ages (Petralia et al., 2005). The pattern of expression of c-Abl indicates that this kinase is more highly expressed during the synaptogenic stages in vivo (Fiala et al., 1998). In addition, c-Abl is enriched in synaptosomal and PSD fractions from adult rat brain (Fig. 4C), validating the postsynaptic distribution of c-Abl in vivo. To evaluate c-Abl/PSD-95 interaction, we performed coimmunoprecipitation assays from total homogenate and synaptosomal 1 fraction obtained from adult rat brain. In total brain homogenate and synaptosomal fraction 1, c-Abl was coimmunoprecipitated with PSD-95 and vice versa (Fig. 4D). Interestingly, PSD-95/c-Abl complex is enriched in the synaptosomal fraction. These results indicate that PSD-95 and c-Abl interact in hippocampal neurons in vitro and, more importantly, that this interaction also takes place in vivo.

Considering this interaction, we analyzed whether PSD-95 is phosphorylated on tyrosine residues by c-Abl. This phosphorylation was assessed in HEK293 cells cotransfected with PSD-95 plus GFP-c-Abl-WT or GFP-c-Abl-KD. PSD-95 immunoprecipitation followed by pTyr immunoblot showed that, in cells cotransfected with PSD-95 plus wild-type c-Abl, there is a strong increase in tyrosine phosphorylation immunoreactivity compared with cells transfected with PSD-95 alone (Fig. 5A). This increase was not observed in cells cotransfected with PSD-95 plus GFP-c-Abl-KD in which PSD-95 tyrosine phosphorylation levels are maintained at control levels as shown by the densitometric analysis (Fig. 5A, graph). In addition, in cells cotransfected with PSD-95 plus GFP-c-Abl-WT and incubated with STI571 for $24 \mathrm{~h}$, we observed a dose-dependent effect of STI571 treatment on PSD-95 tyrosine phosphorylation (Fig. 5B). Expression levels of PSD-95 and c-Abl in transfected HEK293 cells are shown in supplemental Figure 3 (available at www.jneurosci.org as supplemental material). These results suggest that PSD-95 can be phosphorylated on tyrosine residues by c-Abl.

Tyrosine phosphorylation of PSD-95 was also assessed in hippocampal neurons. Immunoprecipitation of PSD-95 and Western blot analysis with anti-pTyr revealed that, under control conditions, PSD-95 is phosphorylated on tyrosine residues (Fig. 5C). Treatment with STI571 for $24 \mathrm{~h}$ decreased tyrosine phosphorylation of PSD-95 in a concentration-dependent manner, as determined by quantification of pTyr levels normalized to total PSD-95 levels in the immunoprecipitate (Fig. 5C, graph). To assess whether there is a direct phosphorylation of PSD-95 by c-Abl, we performed an in vitro phosphorylation assay. Purified c-Abl kinase was incubated with GSTPSD-95 or GST-CrkII, used as a positive control, and $\left[\gamma\right.$-P $\left.{ }^{32}\right]$ ATP, and the transfer of radioactive phosphate was measured. As shown in Figure 5D, we observed a time-dependent increase in GST-PSD-95 phosphorylation by autoradiography and by absorption on $\mathrm{p} 81 \mathrm{cel}-$ 
A

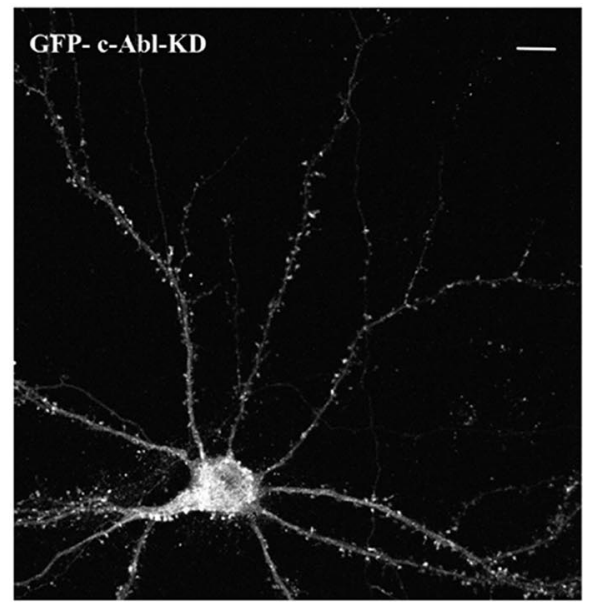

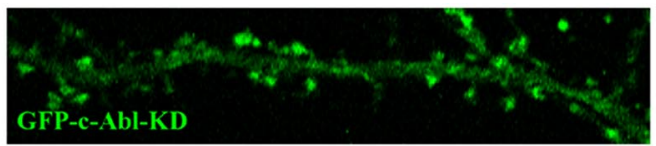
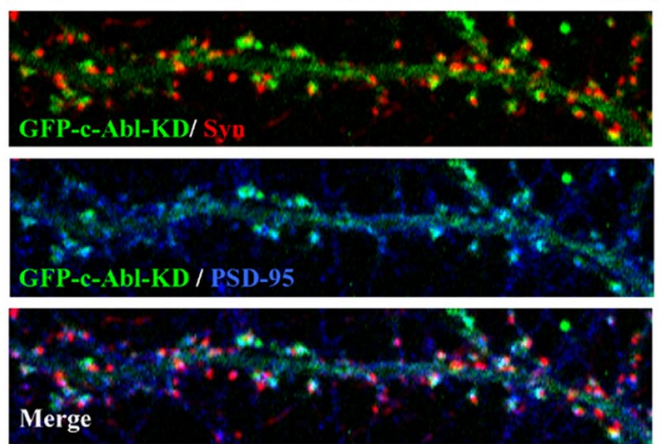

B
GFP

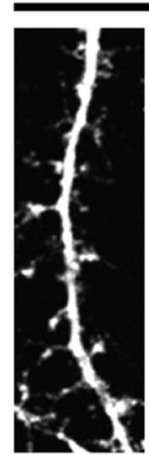

GFP

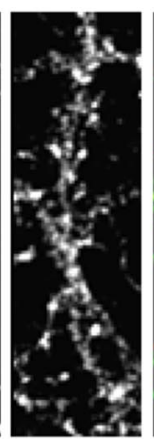

PSD-95 SynI/PSD-95

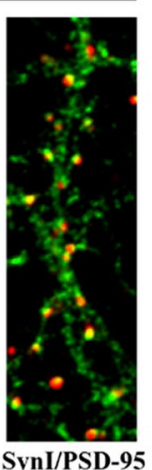

C
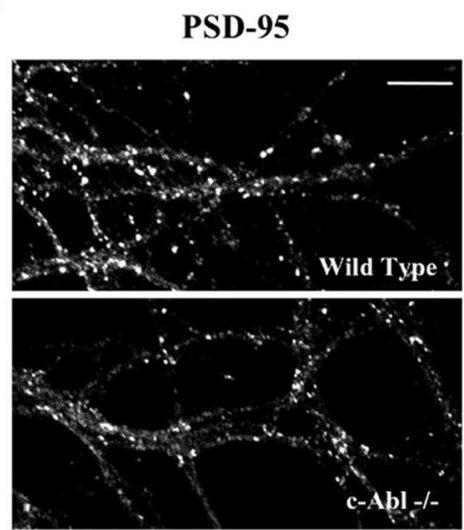

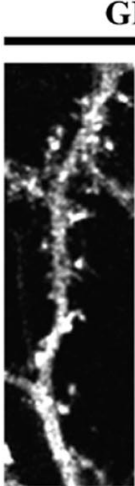

GFP
GFP-c-Abl-KD

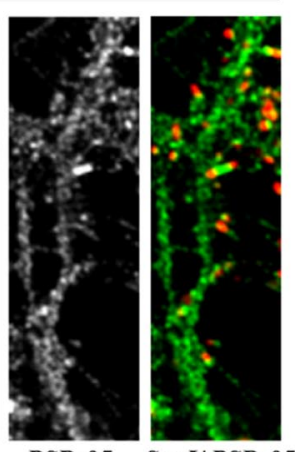

PSD-95 SynI/ PSD-95

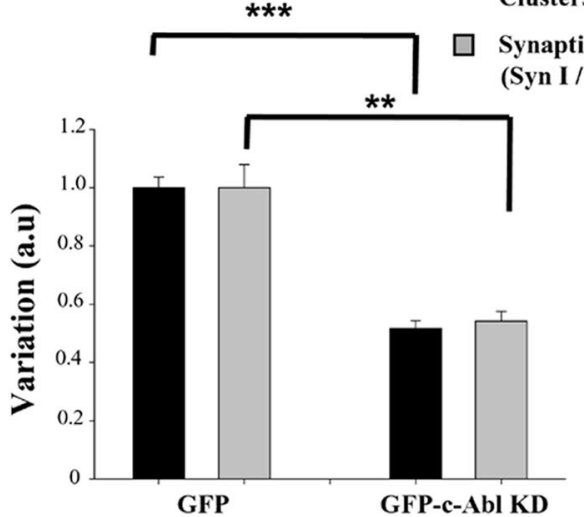

PSD-95 Total Clusters Number Syn I / PSD-95 )
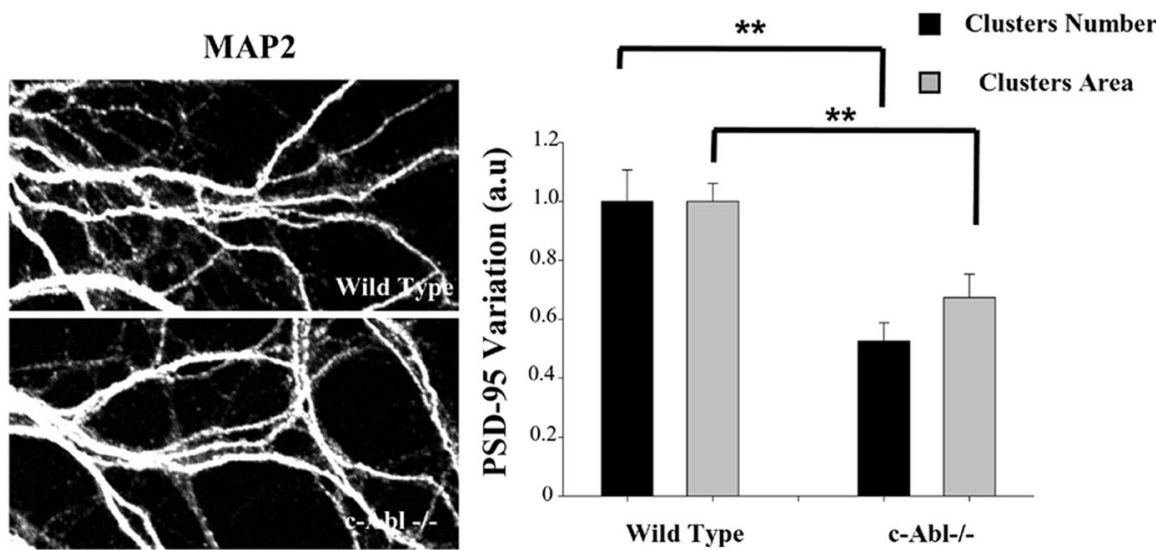

Figure 3. c-Abl kinase activity modulates synaptic clustering of PSD-95. A, Immunodetection of PSD-95 (blue) and Syn I (red) in hippocampal neurons transfected with GFP- c-Abl-KD (green) $2 \mathrm{~d}$ after seeding and maintained in culture for $14 \mathrm{~d}$. B. Representative image and quantification of PSD-95 cluster number and synaptic contact, evaluated as the positives sites for Syn I (red) and PSD-95 (green), by length neurite in transfected neurons with GFP and GFP- C-AbI-KD. Error bars depict SEM. $n=15-20$ transfected neurons $\left({ }^{* *} p<0.01\right.$; $\left.{ }^{* * *} p<0.001\right)$. C, Immunofluorescence of PSD-95 and MAP2 on hippocampal culture (14 DIV) from wild-type and $c-A b I^{-1-}$ mice. The graph shows the quantification of PSD-95 cluster number per $10 \mu \mathrm{m}$ neurite length and PSD-95 cluster area. Scale bar, $5 \mu \mathrm{m}$. Error bars depict SEM of five independent experiment $\left.{ }^{* *} p<0.01\right)$.

lulose phosphate paper (graph). The phosphorylation of GST-PSD95, as well as GST-CrkII, started as early as 5 min of incubation and increased significantly at $90 \mathrm{~min}$. This increase is not observed when c-Abl is inactive (heat denatured or incubated with STI571). Altogether, these results indicate that GST-PSD-95 can be tyrosine phosphorylated by c-Abl.

c-Abl modulates phosphorylation of tyrosine 533 in PSD-95 The regulation of PSD-95 tyrosine phosphorylation by c-Abl activity suggests that this scaffold protein could be a synaptic target of c-Abl. We evaluated c-Abl consensus phosphorylation sites in PSD-95 with online resource NetPhos 2.0 (http://www.cbs.dtu. $\mathrm{dk} /$ services/NetPhos/). This prediction method revealed that PSD-95 contains two tyrosine residues as part of potential c-Abl consensus sequences $\mathrm{YX}_{1-5}$ (P/F) (Cujec et al., 2002; Goss et al., 2006): tyrosine 255 and tyrosine 533 (supplemental Fig. 4, available at www.jneurosci.org as supplemental material). We performed site-directed mutagenesis of both tyrosine residues to alanine in PSD-95 and evaluated tyrosine phosphorylation levels of PSD-95 in HEK293 cells cotransfected with GFP-c-Abl-WT 
or GFP-c-Abl-KD (Fig. 6A). Similar levels of expression were observed in cells transfected with wild-type PSD-95 and the mutants PSD-95(Y255A) and PSD-95(Y533A) (supplemental Fig. 5, available at www. jneurosci.org as supplemental material). As described above, cotransfection of PSD-95 plus GFP-c-Abl-WT induced an increase in tyrosine phosphorylation levels of PSD-95 that was not observed in cells cotransfected with GFP-c-Abl-KD (Fig. $6 A)$. A similar effect was observed with the mutant PSD-95(Y255A), indicating that $\mathrm{Y} 255$ residue is not target of $\mathrm{c}-\mathrm{Abl}$ kinase. In contrast, the mutant PSD95(Y533A) contained significantly less phosphotyrosine than wild-type PSD-95 when cotransfected with GFP-c-Abl-WT (Fig. 6A), suggesting that $\mathrm{Y} 533$ residue is a target of phosphorylation by c-Abl.

To investigate the functional significance of PSD-95 Y533 phosphorylation, we transfected cultured hippocampal neurons with wild-type PSD-95 or PSD-95(Y533A) and analyzed the clustering of this protein at 14 DIV. The mutant PSD-95(Y533A) shows a significant reduction $(22.98 \pm 3.76 \%$; $p<$ $0.001)$ in synaptic clustering compared with wild-type PSD-95 (Fig. 6B), indicating that Y533 residue is relevant for the clustering of this scaffold protein. To assess whether phosphorylation of Y533 is the mechanism involved in the regulatory effect of c-Abl on PSD-95 clustering, hippocampal neurons transfected with wild-type PSD-95 or PSD95(Y533A) were subjected to treatment with $1 \mu \mathrm{M}$ STI571 for $24 \mathrm{~h}$. No additional decrease in PSD-95(Y533) clustering was observed by STI571 treatment. Moreover, the decrease observed in the number of clusters of wild-type PSD-95 by STI571 treatment was similar to the decrease observed in neurons transfected with PSD-95(Y533) without treatment. These results indicate that the regulation of PSD-95 clustering by c-Abl is mediated by Y533 phosphorylation.

\section{Discussion}

Previously, c-Abl localization had been described in synaptic compartments in adult brain hippocampus (Moresco et al., 2003), and it has been postulated that c-Abl could be important in synaptic structure and function (Moresco and Koleske, 2003) and in pathogenesis (Alvarez et al., 2008; Cancino et al., 2008). Here, we report for the first time a role for $\mathrm{c}-\mathrm{Abl}$ on the regulation of PSD-95 clustering in hippocampal neurons. We observed that c-Abl modulates tyrosine phosphorylation of PSD-95, particularly on Y533 residue, and this phosphorylation modulates synaptic clustering of PSD-95.

Treatment with the c-Abl inhibitor STI571 decreased PSD-95 cluster density and area, indicating that c-Abl modulates the synaptic accumulation of this scaffold protein. This treatment did not affect presynaptic protein clustering, suggesting a restricted role of c-Abl in the postsynaptic site. In agreement, localization analysis of c-Abl on 14 DIV neurons revealed that this kinase is mainly located at the postsynaptic region, in which it colocalizes with PSD-95. However, we cannot discard a presynaptic effect because there is a close interaction between the presynaptic and postsynaptic regions; thus, alterations in the organization the postsynaptic region could induce a
B
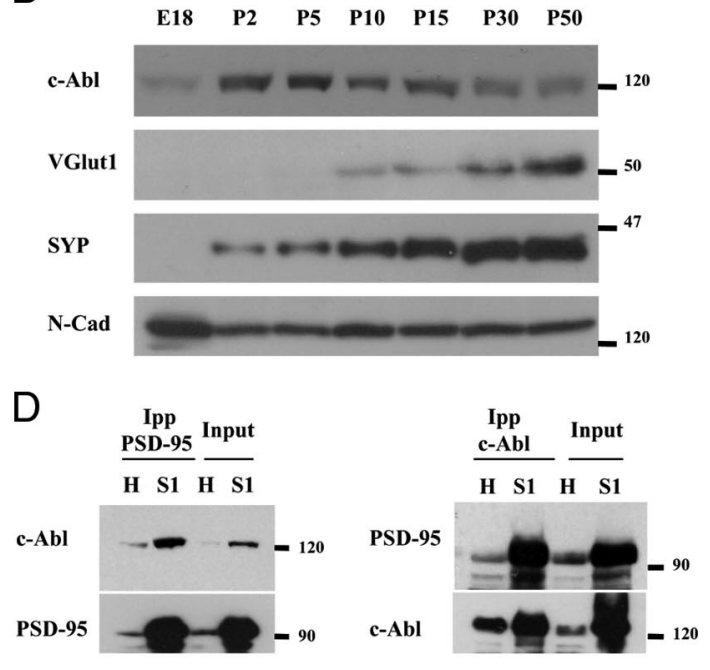

Figure 4. c-Abl interacts with PSD-95, and STI571 modulates PSD-95 tyrosine phosphorylation in hippocampal culture Cun (in 列 mal 1 fraction obtained from adult rat brain. Extracts were immunoprecipitated with antibodies directed against PSD-95 (top) or c-Abl (bottom), and membranes were probed with anti-PSD-95 and anti-c-Abl antibodies. IPP, Immunoprecipitation.

subsequent modification on the presynaptic terminal. Interestingly, in adult mice, $\mathrm{c}$-Abl has an important role in modulation of synaptic efficacy via a presynaptic mechanism during repetitive stimulation (Moresco et al., 2003).

As observed with STI571 treatment, transfection with the dominant-negative form of c-Abl decreased the number of PSD-95 clusters in hippocampal neurons, and, more importantly, hippocampal neurons from $c-A b l^{-1-}$ mice show significantly less PSD-95 clusters than wild-type animals. In these experiments, PSD-95 clustering was evaluated in neurons at 14 DIV. At this culture stage, an increase in the expression and synaptic clustering of the postsynaptic scaffold proteins PSD95, SHANK, and guanylate kinase domain-associated protein (GKAP) has been described (Rao et al., 1998; Petralia et al., 2005; Gerrow et al., 2006), suggesting that c-Abl could be important in the maturation of postsynaptic structure during CNS development. We observed that c-Abl activity inhibition did not affect the clustering of the scaffold protein SHANK or the number of dendritic spines, suggesting a specific effect of c-Abl on PSD-95 regulation and not in the general structure of the postsynaptic compartment. We determined that c-Abl levels increase in the early postnatal stage in rat hippocampus. Consistent with previous reports (Courtney et al., 2000; Moresco et al., 2005), we found that c-Abl has a peak expression at P2-P5 and then decreases steadily until adult stages when it exhibits low levels of expression. Thus, c-Abl could modulate synaptic clustering of PSD-95 mainly during early developmental stages.

It has been determined that serine/threonine kinases modulates PSD-95 functions (Yoshimura et al., 2002; Morabito et al., 2004; Sabio et al., 2004; Soto et al., 2004; Gardoni et al., 2006; Kim et al., 2007; Steiner et al., 2008; Farías et al., 2009). Recently, it was 


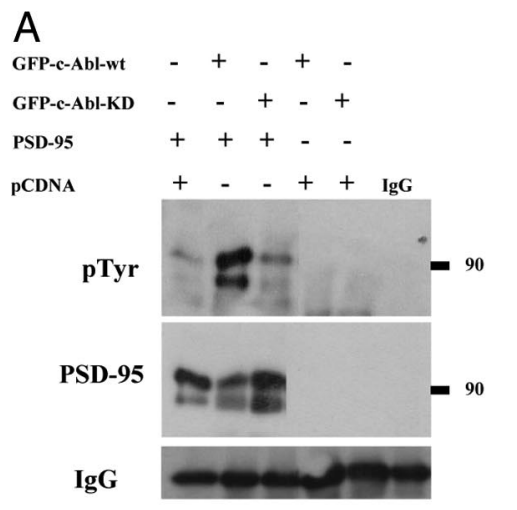

C

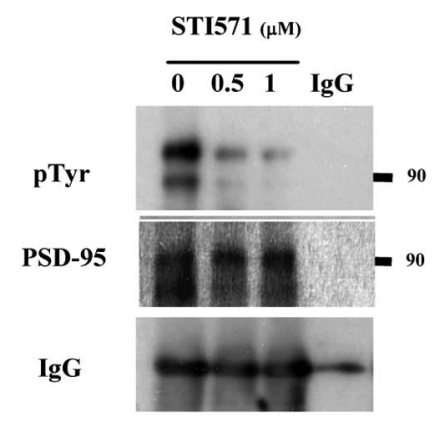

D
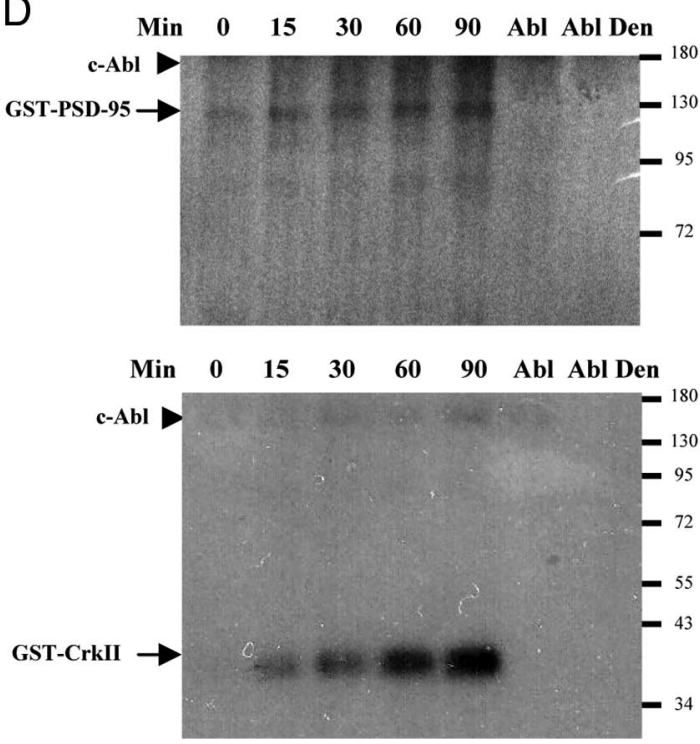

B

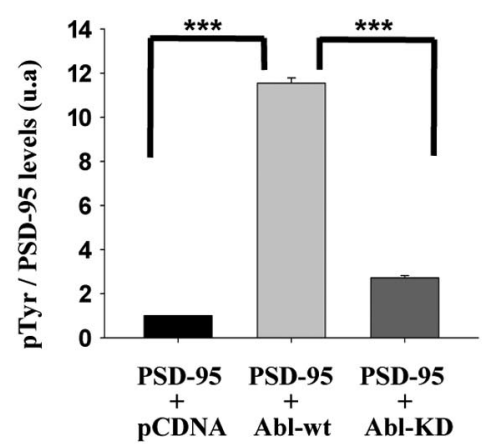

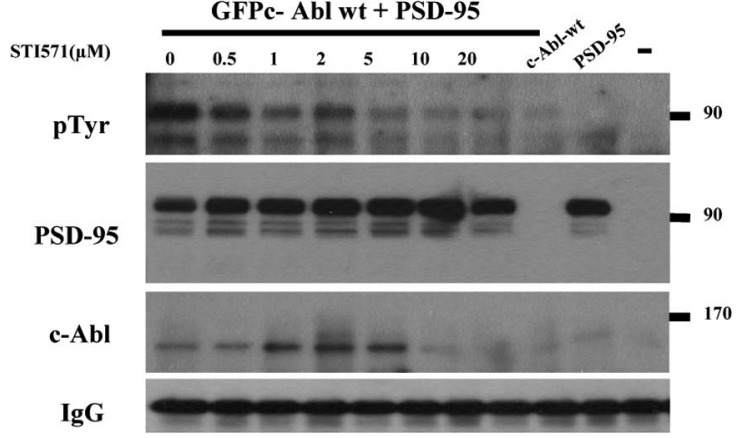
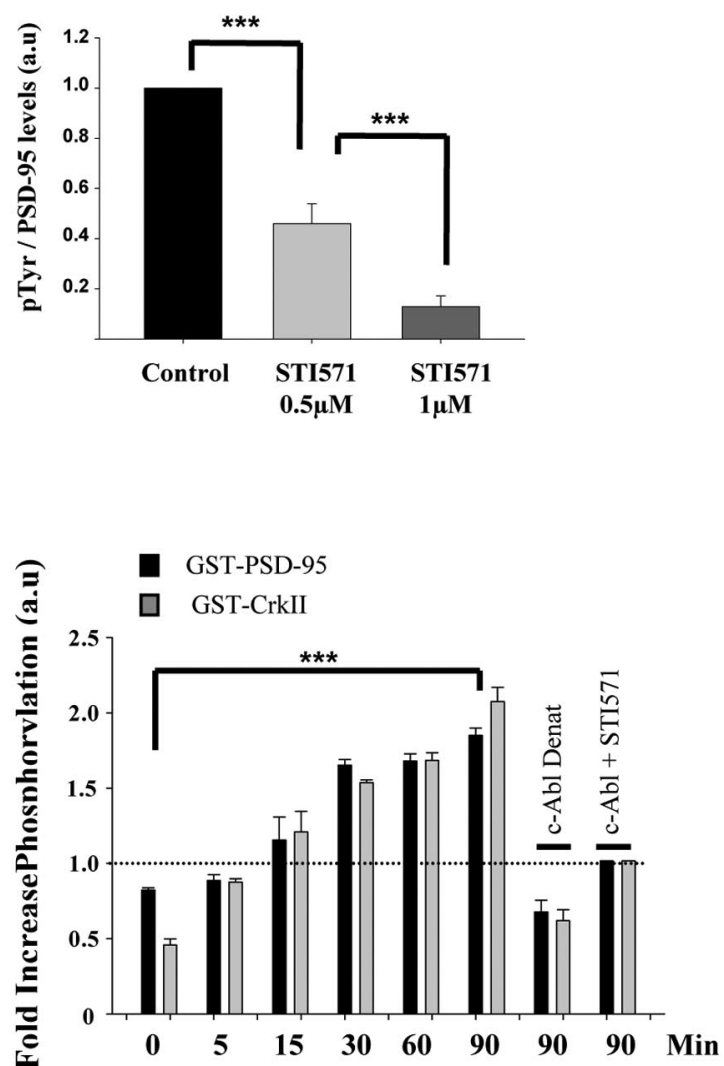

Figure 5. PSD-95 tyrosine phosphorylation is regulated by c-Abl activity. A, HEK293 cells were cotransfected with PSD-95 plus GFP- c-Abl-WT or GFP- c-Abl-KD or the empty vector (pcDNA). PSD-95 was immunoprecipitated, and the membrane was probed with anti-pTyr and anti-PSD-95. Error bars depict SEM of four independent experiments. $\boldsymbol{B}$, PSD-95 was immunoprecipitated from HEK293 cells cotransfected with PSD-95 plus GFP-c-Abl-WT $24 \mathrm{~h}$ after transfection. Cells were incubated with different concentration of STI571 for $24 \mathrm{~h}$. Western blot was incubated with pTyr, PSD-95, and c-Abl. C, Immunoprecipitation of PSD-95 from total extracts of hippocampal neurons treated with 0.5 or $1 \mu \mathrm{M}$ STI571 for $24 \mathrm{~h}$. Western blot was probed with anti-pTyr and anti-PSD-95 antibodies. Molecular weight standards are indicated at the right (in kilodaltons). Error bars depict SEM of six independent experiments $\left({ }^{* * *} p<0.001\right)$. D, In vitro phosphorylation assay was performed by incubating GST-PSD-95 or GST-Crkll (positive control) with c-Abl kinase at different times ( $0-90 \mathrm{~min})$. The radioactivity was monitored by SDS-PAGE and autoradiography and additionally by absorption in P81 paper and scintillation counter. The radioactivity incorporation for each substrate was normalized against c-Abl incubated for 90 min with $0.5 \mu$ Ci of [ $\gamma^{-}{ }^{32}$ P]ATP but without a substrate (dotted line). Arrowheads show autophosphorylated c-Abl. Error bars depict SEM of four independent experiments $\left({ }^{* * *} p<0.001\right)$. a.u., Arbitrary units; Den or Denat, denatured.

found that Src family kinases regulate tyrosine phosphorylation of PSD-95 on a tyrosine important for glutamate or NMDAmediated current (Du et al., 2009). Thus, tyrosine phosphorylation could be a posttranslational mechanism important for the regulation of the functions of this scaffold protein. Herein, we determined that (1) c-Abl coimmunoprecipitates with PSD-95 in vitro and in vivo, (2) c-Abl mediates tyrosine phosphorylation of PSD-95 in hippocampal neurons; and (3) c-Abl directly phosphorylates PSD-95 as determined by in vitro phosphorylation assays. More importantly, by inhibiting c-Abl kinase activity, we were able to modulate synaptic clustering of PSD-95, revealing c-Abl as a novel kinase involved in the regulation PSD-95. 
Although our results strongly support a postsynaptic role of c-Abl, morphological and synaptic abnormalities have not been detected in adult $c$-Abl ${ }^{-/-}$mutant mouse brain (Koleske et al., 1998; Moresco et al., 2003). It has been suggested that $\mathrm{c}-\mathrm{Abl}$ has overlapping roles with another member of Abl family kinase, Arg (Abl related-gene). Arg and c-Abl kinases have different expression patterns during development, with Arg being more highly expressed in adult brain (Hernández et al., 2004; Moresco et al., 2005). Therefore, it is possible that Arg could compensate for c-Abl functions in $c-A b l^{-/-}$mice; in that case, Arg kinase could modulate PSD-95 clustering in $c-A b l^{-1-}$ mice. It would be informative to evaluate PSD-95 clustering in the absence of both kinases, although the double mutant $c-A b l^{-/-} A r g^{-/-}$mice present alterations on morphogenesis of neuroepithelial cells during neurulation and die at embryonic day 10.5 (Koleske et al., 1998).

Our experiments show that there is an interaction of c-Abl and PSD-95 and that PSD-95 is phosphorylated at Y533 in a c-Abl-dependent manner, because PSD-95 mutant PSD-95(Y533A) is less phosphorylated than wild-type PSD-95 or the mutant PSD-95(Y255A) in the presence of wildtype c-Abl. Therefore, these c-Abl modules are good candidates to mediate its association with PSD-95. Sequence analysis revealed two putative conserved residues (Y63 and Y523) that could be recognized by c-Abl-Src homology 2 (SH2) domain (supplemental Fig. 6, available at www.jneurosci. org as supplemental material). Interestingly, it has been described that Y523 in PSD-95 is phosphorylated by Src/Fyn kinase (Du et al., 2009), and this phosphorylated tyrosine could be recognized by c-Abl-SH2 domain, therefore promoting Y533 phosphorylation by c-Abl. If that is the case, both tyrosine kinases could collectively modulate PSD-95 phosphorylation. This could explain why our mutation at Y533 did not completely abolish PSD-95 tyrosine phosphorylation.

Structurally, PSD-95 has a multidomain structure consisting of protein-protein interaction modules: three N-terminal PDZ (PSD95/Discs large/zona occludens-1) domains, one SH3 domain, and one C-terminal guanylate kinase homology (GK) domain (Cho et al., 1992; Kim et al., 1995; Kornau et al., 1995). Considering the proximity of Y533 to the GK domain of PSD-95 [residues 534-713 (Tavares et al., 2001)], it is possible that the phosphorylation at Y533 could be relevant for the functions associated with this domain. For instance, the GK domain interacts with GKAP (Kim et al., 1997; Takeuchi et al., 1997) and AKAP79/150 [A kinase (PRKA) anchor protein 79/150] (Colledge et al., 2000) and indirectly recruits the scaffold protein SHANK to the PSD (Naisbitt et al., 1999). This domain is also involved in spine growth (Steiner et al., 2008) and forms a complex with SPAR (surfactant protein A binding protein), a RapGAP modulating spine morphology through reorganization of the actin cytoskeleton (Pak et al., 2001). Thus, it is possible that phosphorylation of PSD-95 at Y533 affects the association of the GK domain with some of these proteins and, as a result, modulates PSD-95 clustering and therefore the postsynaptic structure. PSD-95 assumes a synaptic localization early during network formation (Rao et al., 1998; Scheiffele et al., 2000; Gerrow et al., 2006), and it has been suggested that it plays important roles in synapse formation (Bresler et al., 2001). In this study, we show evidence that c-Abl activity is necessary for the synaptic accumulation of PSD-95, but the mechanism involved in the clustering of PSD-95 mediated by c-Abl phosphorylation remains unclear. It has been observed that de novo PSD-95 clusters can form by recruitment from a diffuse pool of PSD-95 into the synapse with no obvious involvement of discernible transport particles (Bresler et al., 2001). In contrast, it has been reported that the splitting of PSD-95 clusters can occur in neuronal cultures (Gerrow et al., 2006). Future experiments will aim to elucidate how Y533 phosphorylation modulates the synaptic clustering of PSD-95 and to determine whether it involves the recruitment of PSD-95 from a diffusible pool or the splitting of previously formed clusters. Finally, does c-Abl modulate glutamate receptor clustering and function through its effect on PSD95? It is known that PSD-95 is a binding partner of the NR2 subunit of NMDA receptors and seems to regulate NMDA receptor activity and signaling rather than its clustering at the synapse (Kornau et al., 1995). In contrast, a role for PSD-95 in regulating AMPA receptor insertion and retention at the synapse has been widely documented. Overexpression of PSD-95 was shown to enhance AMPA receptor recruitment and excitatory synaptic responses without affecting NMDA receptor clustering in developing hippocampal neurons (El-Husseini et al., 2000a). The effects of PSD-95 on AMPA receptor clustering is modulated through association with stargazin and related family members (Chen et al., 2000; Schnell et al., 2002; Dakoji et al., 2003). Other studies have also shown that PSD-95 levels influences AMPA receptor 
retention and activity at the synapse (Ehrlich and Malinow, 2004; Schlüter et al., 2006), and mice lacking PSD-95 show reduced AMPA receptor function (Migaud et al., 1998; Béïque et al., 2006; Ehrlich et al., 2007). As expected from this evidence and the role suggested for $\mathrm{c}-\mathrm{Abl}$ in the present work, a significant reduction in GluR1 cluster density was observed in neurons treated with STI571, suggesting that c-Abl could indirectly modulate AMPA receptor through the clustering of PSD-95. Additional experiments are necessary to corroborate this hypothesis.

In summary, our results show that c-Abl kinase modulates PSD-95 phosphorylation and clustering, supporting a synaptogenic role for this kinase. In addition, our data show for the first time that PSD-95 clustering is modulated by tyrosine phosphorylation, providing an additional regulatory mechanism for this key component of the PSD.

\section{References}

Alvarez AR, Sandoval PC, Leal NR, Castro PU, Kosik KS (2004a) Activation of the neuronal c-Abl tyrosine kinase by amyloid-beta-peptide and reactive oxygen species. Neurobiol Dis 17:326-336.

Alvarez AR, Godoy JA, Mullendorff K, Olivares GH, Bronfman M, Inestrosa NC (2004b) Wnt-3a overcomes beta-amyloid toxicity in rat hippocampal neurons. Exp Cell Res 297:186-196.

Alvarez AR, Klein A, Castro J, Cancino GI, Amigo J, Mosqueira M, Vargas LM, Yévenes LF, Bronfman FC, Zanlungo S (2008) Imatinib therapy blocks cerebellar apoptosis and improves neurological symptoms in a mouse model of Niemann-Pick type C disease. FASEB J 22:3617-3627.

Beazely MA, Weerapura M, Macdonald JF (2008) Abelson tyrosine kinase links PDGFbeta receptor activation to cytoskeletal regulation of NMDA receptors in CA1 hippocampal neurons. Mol Brain 1:20.

Béïque JC, Lin DT, Kang MG, Aizawa H, Takamiya K, Huganir RL (2006) Synapse-specific regulation of AMPA receptor function by PSD-95. Proc Natl Acad Sci U S A 103:19535-19540.

Boulland JL, Qureshi T, Seal RP, Rafiki A, Gundersen V, Bergersen LH, Fremeau RT Jr, Edwards RH, Storm-Mathisen J, Chaudhry FA (2004) Expression of the vesicular glutamate transporters during development indicates the widespread corelease of multiple neurotransmitters. J Comp Neurol 480:264-280.

Bresler T, Ramati Y, Zamorano PL, Zhai R, Garner CC, Ziv NE (2001) The dynamics of SAP90/PSD-95 recruitment to new synaptic junctions. Mol Cell Neurosci 18:149-167.

Cancino GI, Toledo EM, Leal NR, Hernandez DE, Yévenes LF, Inestrosa NC, Alvarez AR (2008) STI571 prevents apoptosis, tau phosphorylation and behavioural impairments induced by Alzheimer's beta-amyloid deposits. Brain 131:2425-2442.

Carlin RK, Grab DJ, Cohen RS, Siekevitz P (1980) Isolation and characterization of postsynaptic densities from various brain regions: enrichment of different types of postsynaptic densities. J Cell Biol 86:831-845.

Chen L, Chetkovich DM, Petralia RS, Sweeney NT, Kawasaki Y, Wenthold RJ, Bredt DS, Nicoll RA (2000) Stargazin regulates synaptic targeting of AMPA receptors by two distinct mechanisms. Nature 408:936-943.

Chen S, O'Reilly LP, Smithgall TE, Engen JR (2008) Tyrosine phosphorylation in the $\mathrm{SH} 3$ domain disrupts negative regulatory interactions within the c-Abl kinase core. J Mol Biol 383:414-423.

Cho KO, Hunt CA, Kennedy MB (1992) The rat brain postsynaptic density fraction contains a homolog of the Drosophila discs-large tumor suppressor protein. Neuron 9:929-942.

Colledge M, Dean RA, Scott GK, Langeberg LK, Huganir RL, Scott JD (2000) Targeting of PKA to glutamate receptors through a MAGUK-AKAP complex. Neuron 27:107-119.

Corbin AS, Buchdunger E, Pascal F, Druker BJ (2002) Analysis of the structural basis of specificity of inhibition of the Abl kinase by STI571. J Biol Chem 277:32214-32219.

Courtney KD, Grove M, Vandongen H, Vandongen A, LaMantia AS, Pendergast AM (2000) Localization and phosphorylation of Ablinteractor proteins, $\mathrm{Abi}-1$ and $\mathrm{Abi}-2$, in the developing nervous system. Mol Cell Neurosci 16:244-257.

Craven SE, El-Husseini AE, Bredt DS (1999) Synaptic targeting of the postsynaptic density protein PSD-95 mediated by lipid and protein motifs. Neuron 22:497-509.
Cujec TP, Medeiros PF, Hammond P, Rise C, Kreider BL (2002) Selection of $\mathrm{v}$-abl tyrosine kinase substrate sequences from randomized peptide and cellular proteomic libraries using mRNA display. Chem Biol 9:253-264.

Dakoji S, Tomita S, Karimzadegan S, Nicoll RA, Bredt DS (2003) Interaction of transmembrane AMPA receptor regulatory proteins with multiple membrane associated guanylate kinases. Neuropharmacology 45:849-856.

Du CP, Gao J, Tai JM, Liu Y, Qi J, Wang W, Hou XY (2009) Increased tyrosine phosphorylation of PSD-95 by Src family kinases after brain ischaemia. Biochem J 417:277-285.

Ehrlich I, Malinow R (2004) Postsynaptic density 95 controls AMPA receptor incorporation during long-term potentiation and experience-driven synaptic plasticity. J Neurosci 24:916-927.

Ehrlich I, Klein M, Rumpel S, Malinow R (2007) PSD-95 is required for activity-driven synapse stabilization. Proc Natl Acad Sci U S A 104: $4176-4181$

El-Husseini AE, Schnell E, Chetkovich DM, Nicoll RA, Bredt DS (2000a) PSD-95 involvement in maturation of excitatory synapses. Science 290:1364-1368.

El-Husseini AE, Craven SE, Chetkovich DM, Firestein BL, Schnell E, Aoki C, Bredt DS (2000b) Dual palmitoylation of PSD-95 mediates its vesiculotubular sorting, postsynaptic targeting, and ion channel clustering. J Cell Biol 148:159-172.

Farías GG, Alfaro IE, Cerpa W, Grabowski CP, Godoy JA, Bonansco C, Inestrosa NC (2009) WNT-5a/JNK signaling promotes the clustering of PSD-95 in hippocampal neurons. J Biol Chem 284:15857-15866.

Fiala J, Feinberg M, Popov V, Harris K (1998) Synaptogenesis via dendritic filopodia in developing hippocampal area CA1. J Neurosci 18: $8900-8911$.

Finn AJ, Feng G, Pendergast AM (2003) Postsynaptic requirement for Abl kinases in assembly of the neuromuscular junction. Nat Neurosci 6:717-723.

Friedman HV, Bresler T, Garner CC, Ziv NE (2000) Assembly of new individual excitatory synapses: time course and temporal order of synaptic molecule recruitment. Neuron 27:57-69.

Gardoni F, Polli F, Cattabeni F, Di Luca M (2006) Calcium-calmodulindependent protein kinase II phosphorylation modulates PSD-95 binding to NMDA receptors. Eur J Neurosci 24:2694-2704.

Gerrow K, Romorini S, Nabi SM, Colicos MA, Sala C, El-Husseini A (2006) A preformed complex of postsynaptic proteins is involved in excitatory synapse development. Neuron 49:547-562.

Goss VL, Lee KA, Moritz A, Nardone J, Spek EJ, MacNeill J, Rush J, Comb MJ, Polakiewicz RD (2006) A common phosphotyrosine signature for the Bcr-Abl kinase. Blood 107:4888-4897.

Hernández SE, Settleman J, Koleske AJ (2004) Adhesion-dependent regulation of p190RhoGAP in the developing brain by the Abl-related gene tyrosine kinase. Curr Biol 14:691-696.

Jones SB, Lu HY, Lu Q (2004) Abl tyrosine kinase promotes dendrogenesis by inducing actin cytoskeletal rearrangements in cooperation with Rho family small GTPases in hippocampal neurons. J Neurosci 24:8510-8521.

Kaech S, Banker G (2006) Culturing hippocampal neurons. Nat Protoc 1:2406-2415.

Kim E, Sheng M (2004) PDZ domain proteins of synapses. Nat Rev Neurosci 5:771-781.

Kim E, Niethammer M, Rothschild A, Jan YN, Sheng M (1995) Clustering of Shaker-type $\mathrm{K}^{+}$channels by interaction with a family of membraneassociated guanylate kinases. Nature 378:85-88.

Kim E, Naisbitt S, Hsueh YP, Rao A, Rothschild A, Craig AM, Sheng M (1997) GKAP, a novel synaptic protein that interacts with the guanylate kinase-like domain of the PSD-95/SAP90 family of channel clustering molecules. J Cell Biol 136:669-678.

Kim MJ, Futai K, Jo J, Hayashi Y, Cho K, Sheng M (2007) Synaptic accumulation of PSD-95 and synaptic function regulated by phosphorylation of serine-295 of PSD-95. Neuron 56:488-502.

Kistner U, Wenzel BM, Veh RW, Cases-Langhoff C, Garner AM, Appeltauer U, Voss B, Gundelfinger ED, Garner CC (1993) SAP90, a rat presynaptic protein related to the product of the Drosophila tumor suppressor gene dlg-A. J Biol Chem 268:4580-4583.

Koleske AJ, Gifford AM, Scott ML, Nee M, Bronson RT, Miczek KA, Baltimore D (1998) Essential roles for the Abl and Arg tyrosine kinases in neurulation. Neuron 21:1259-1272.

Kornau HC, Schenker LT, Kennedy MB, Seeburg PH (1995) Domain inter- 
action between NMDA receptor subunits and the postsynaptic density protein PSD-95. Science 269:1737-1740.

Lanier LM, Gertler FB (2000) From Abl to actin: Abl tyrosine kinase and associated proteins in growth cone motility. Curr Opin Neurobiol 10: $80-87$.

Migaud M, Charlesworth P, Dempster M, Webster LC, Watabe AM, Makhinson M, He Y, Ramsay MF, Morris RG, Morrison JH, O’Dell TJ, Grant SG (1998) Enhanced long-term potentiation and impaired learning in mice with mutant postsynaptic density-95 protein. Nature 396:433-439.

Morabito MA, Sheng M, Tsai LH (2004) Cyclin-dependent kinase 5 phosphorylates the $\mathrm{N}$-terminal domain of the postsynaptic density protein PSD-95 in neurons. J Neurosci 24:865-876.

Moresco EM, Koleske AJ (2003) Regulation of neuronal morphogenesis and synaptic function by Abl family kinases. Curr Opin Neurobiol 13:535-544.

Moresco EM, Scheetz AJ, Bornmann WG, Koleske AJ, Fitzsimonds RM (2003) Abl family nonreceptor tyrosine kinases modulate short-term synaptic plasticity. J Neurophysiol 89:1678-1687.

Moresco EM, Donaldson S, Williamson A, Koleske AJ (2005) Integrinmediated dendrite branch maintenance requires Abelson (Abl) family kinases. J Neurosci 25:6105-6118.

Naisbitt S, Kim E, Tu JC, Xiao B, Sala C, Valtschanoff J, Weinberg RJ, Worley PF, Sheng M (1999) Shank, a novel family of postsynaptic density proteins that binds to the NMDA receptor/PSD-95/GKAP complex and cortactin. Neuron 23:569-582.

Pak DT, Yang S, Rudolph-Correia S, Kim E, Sheng M (2001) Regulation of dendritic spine morphology by SPAR, a PSD-95-associated RapGAP. Neuron 31:289-303.

Petralia RS, Sans N, Wang YX, Wenthold RJ (2005) Ontogeny of postsynaptic density proteins at glutamatergic synapses. Mol Cell Neurosci 29:436-452.

Prange O, Murphy TH (2001) Modular transport of postsynaptic density-95 clusters and association with stable spine precursors during early development of cortical neurons. J Neurosci 21:9325-9333.

Rao A, Kim E, Sheng M, Craig AM (1998) Heterogeneity in the molecular composition of excitatory postsynaptic sites during development of hippocampal neurons in culture. J Neurosci 18:1217-1229.

Sabio G, Reuver S, Feijoo C, Hasegawa M, Thomas GM, Centeno F, Kuhlendahl S, Leal-Ortiz S, Goedert M, Garner C, Cuenda A (2004) Stress- and mitogen-induced phosphorylation of the synapse-associated protein SAP90/PSD-95 by activation of SAPK3/p38gamma and ERK1/ERK2. Biochem J 380:19-30.

Sala C, Piëch V, Wilson NR, Passafaro M, Liu G, Sheng M (2001) Regulation of dendritic spine morphology and synaptic function by Shank and Homer. Neuron 31:115-130.
Scheiffele P, Fan J, Choih J, Fetter R, Serafini T (2000) Neuroligin expressed in nonneuronal cells triggers presynaptic development in contacting axons. Cell 101:657-669.

Schlüter OM, Xu W, Malenka RC (2006) Alternative N-terminal domains of PSD-95 and SAP97 govern activity-dependent regulation of synaptic AMPA receptor function. Neuron 51:99-111.

Schnell E, Sizemore M, Karimzadegan S, Chen L, Bredt DS, Nicoll RA (2002) Direct interactions between PSD-95 and stargazin control synaptic AMPA receptor number. Proc Natl Acad Sci U S A 99:13902-13907.

Soto D, Pancetti F, Marengo JJ, Sandoval M, Sandoval R, Orrego F, Wyneken U (2004) Protein kinase CK2 in postsynaptic densities: phosphorylation of PSD-95/SAP90 and NMDA receptor regulation. Biochem Biophys Res Commun 322:542-550.

Steiner P, Higley MJ, Xu W, Czervionke BL, Malenka RC, Sabatini BL (2008) Destabilization of the postsynaptic density by PSD-95 serine 73 phosphorylation inhibits spine growth and synaptic plasticity. Neuron 60:788-802.

Takeuchi M, Hata Y, Hirao K, Toyoda A, Irie M, Takai Y (1997) SAPAPs. A family of PSD-95/SAP90-associated proteins localized at postsynaptic density. J Biol Chem 272:11943-11951.

Tanis KQ, Veach D, Duewel HS, Bornmann WG, Koleske AJ (2003) Two distinct phosphorylation pathways have additive effects on Abl family kinase activation. Mol Cell Biol 23:3884-3896.

Tavares GA, Panepucci EH, Brunger AT (2001) Structural characterization of the intramolecular interaction between the $\mathrm{SH} 3$ and guanylate kinase domains of PSD-95. Mol Cell 8:1313-1325.

Tybulewicz VL, Crawford CE, Jackson PK, Bronson RT, Mulligan RC (1991) Neonatal lethality and lymphopenia in mice with a homozygous disruption of the c-abl proto-oncogene. Cell 65:1153-1163.

Woodring PJ, Litwack ED, O'Leary DD, Lucero GR, Wang JY, Hunter T (2002) Modulation of the F-actin cytoskeleton by c-Abl tyrosine kinase in cell spreading and neurite extension. J Cell Biol 156:879-892.

Wyneken U, Smalla KH, Marengo JJ, Soto D, de la Certa A, Tischmeyer W, Grimm R, Boeckers TM, Wolf G, Orrego F, Gundelfinger ED (2001) Kainate-induced seizures alter protein composition and N-methyl-Daspartate receptor function of rat forebrain postsynaptic densities. Neuroscience 102:65-74.

Yoshimura Y, Shinkawa T, Taoka M, Kobayashi K, Isobe T, Yamauchi T (2002) Identification of protein substrates of $\mathrm{Ca}^{2+} /$ calmodulin-dependent protein kinase II in the postsynaptic density by protein sequencing and mass spectrometry. Biochem Biophys Res Commun 290:948-954.

Zukerberg LR, Patrick GN, Nikolic M, Humbert S, Wu CL, Lanier LM, Gertler FB, Vidal M, Van Etten RA, Tsai LH (2000) Cables links Cdk5 and c-Abl and facilitates Cdk5 tyrosine phosphorylation, kinase upregulation, and neurite outgrowth. Neuron 26:633-646. 